\title{
PENGARUH MODAL SOSIAL, KOMPENTENSI GURU DAN INTENSITAS KEGIATAN MGMP TERHADAP PROFESIONALISME GURU IPS SMP
}

\section{EFFECTS OF SOCIAL CAPITAL, TEACHER COMPETENCE AND INTENSITY OF ACTIVITY MGMPS IN THE PROFESSIONALISM OF SOCIAL STUDIES TEACHERS IN JUNIOR HIGH SCHOOL}

\author{
Reza Armin Abdillah Dalimunthe, Farida Hanum \\ Pendidikan IPS, Universitas Negeri Yogyakarta \\ Karangmalang, Yogyakarta, 55218 \\ Rezaabdillahdalimunthe@gmail.com
}

\begin{abstract}
Abstrak
Tujuan penelitian ini untuk mengetahui pengaruh modal sosial, kompetensi guru, dan intensitas kegiatan MGMP terhadap profesionalisme guru SMP IPS Kota Yogyakarta. Penelitian ini merupakan penelitian ex-post facto dengan pendekatan kuantitatif. Sampel penelitian ini adalah guru IPS SMP yang tergabung dalam MGMP Yogyakarta. Terdapat 109 guru yang diambil seluruhnya menggunakan teknik sampel jenuh. Pengumpulan data menggunakan quesioner untuk variabel modal sosial, kompetensi guru, intensitas kegiatan MGMP dan profesionalisme guru. Pengujian validitas instrument dilakukan dengan expert judgment dan analisis faktor, sedangkan uji reliabilitas menggunakan Alfa Cronbach. Analisis data menggunakan teknik regresi linier sederhana dan ganda. Hasil penelitian menunjukkan bahwa modal sosial bepengaruh signifikan terhadap profesionalisme guru, kompetensi guru berpengaruh signifikan terhadap profesionalisme guru, intensitas kegiatan MGMP berpengaruh signifikan terhadap profesionalisme guru, serta modal sosial, kompetensi guru dan intensitas kegiatan MGMP secara bersama-sama berpengaruh signifikan terhadap profesionalisme guru SMP IPS Kota Yogyakarta.
\end{abstract}

Kata Kunci: .Modal Sosial, Kompetensi Guru, Intensitas Kegiatan MGMP, Profesionalisme Guru

\begin{abstract}
The aim of this study to determine the effect of social capital, the competence of teachers, and the intensity of activity on the professionalism of junior high school MGMP IPS teachers in Yogyakarta. This study is an ex-post facto quantitative approach.The samples were junior high school social studies teacher who joined in MGMPS Yogyakarta. There are 109 teachers drawn entirely using sampling techniques saturated. Collecting data using questionnaires for social capital variables, teacher competence, the intensity of activity MGMPs and professionalism of teachers. Testing the validity of the instrument performed by expert judgment and factor analysis, while the reliability test using Cronbach Alpha. Analysis of data using simple linear regression technique and a double. The results showed that social capital significantly effect on the professionalism of teachers, teacher competence significantly effect on the professionalism of teachers, the intensity of activity MGMPs significantly effect on the professionalism of teachers, as well as social capital, competence of teachers and intensity MGMPs activities simultaneous significant effect on teacher professionalism of junior high school MGMP IPS teachers in Yogyakarta.
\end{abstract}

Keywords: Social Capital, Teacher Competence, Intensity of MGMPs Activities, Teacher Professionalism 


\section{Pendahuluan}

Ilmu pengetahuan merupakan dasar perubahan dalam membangun sebuah peradaban. Pendidikan memiliki peranan penting terhadap peningkatan kualitas sumber daya manusia dan kualitas kehidupan suatu Negara. Dalam upaya peningkatan mutu pendidikan, Indonesia selalu mencanangkan kegiatan dan program yang diharapkan mampu meningkatkan kualitas guru atau tenaga pengajar.

Guru memiliki peran sentral dalam meningkatkan kualitas pendidikan. Sebagai ujung tombak pendidikan guru mempunyai peranan langsung untuk berinteraksi dengan peserta didik dalam pembelajaran di kelas. Artinya, kualitas pendidikan pada sebuah sekolah dapat tercerminkan dari kualitas proses pembelajaran yang dilakukan oleh guru di dalam kelas. Keberadaan guru yang berkualitas sangat diperlukan untuk menunjang kegiatan belajar mengajar di kelas.

Kemajuan pendidikan merupakan suatu aspek kehidupan yang sangat mendasar bagi pembangunan suatu negara. Selain memerlukan sumber daya alam, juga diperlukan sumber daya manusia yang berkualitas. Upaya untuk menciptakan dan meningkatkan sumber daya manusia itu dapat ditempuh melalui pendidikan. Dunia pendidikan diharapkan bisa menjadi salah satu wahana untuk mempersiapkan generasi bangsa, sehingga munculah sumber daya manusia yang handal dan mempunyai kemampuan untuk menghadapi dinamika perkembangan ilmu pengetahuan dan teknologi di dunia modern (Eka, 2014, p131).

Mutu pendidikan di Indonesia secara kualitas masih tergolong rendah. Seperti yang dilansir dari hasil penelitian Programme for International Study Assessment (PISA) 2012 diamana mutu pendidikan Indonesia masih tertinggal dibandingkan dengan negara tetangga seperti, Malaysia, Singapura, dan Filipina. Data PISA menempatkan Indonesia pada posisi terbawah kedua dari 65 negara yang diteliti dalam hal pencapaian mutu pendidikan. Penelitian tersebut memperlihatkan ada sesuatu yang salah dalam sistem dan kebijakan pendidikan di Indonesia.

Kualitas guru sebagai komponen utama dalam proses pendidikan belum memadai. Data statistik The United Nations Development Programme (UNDP) tentang Human Development Index (HDI) Indonesia yang menempati peringkat 108 dari 187 negara. Posisi tersebut kalah jauh dari Singapura, Malaysia, dan Thailand,yang masing-masing berada pada posisi 9, 62, dan 89. Di Indonesia terdapat $60 \%$ guru $\mathrm{SD}, 40 \%$ guru SMP, $43 \%$ guru SMA, dan 34\% guru SMK masih dianggap belum layak untuk mengajar di jenjang masingmasing (UNDP, 2014). Data lain yang lebih memprihatinkan adalah penelitian dari Konsorsium Ilmu Pendidikan memperlihatkan bahwa $40 \%$ guru SMP dan 33\% guru SMA mengajar bidang studi di luar bidang keahliannya (Utami, 2003, p.1).

Paparan di atas menggambarkan bahwa guru di Indonesia belum mencapai pada kata ideal. Hal tersebut terlihat karena masih terdapat kecenderungan ketidaksesuaian latar belakang pendidikan dan kurang maksimalnya guru dalam memenuhi kompetensi yang mendukung profesionalisme guru. Demikian juga yang terjadi di Kota Yogyakarta, berdasarkan wawancara yang dilakukan Kepala Dinas Pendidikan Kota Yogyakarta pada tanggal 22 Juni 2015 beliau mengatakan bahwa salah satu kunci dalam keberhasilan dalam program pendidikan adalah peningkatan kualitas guru. Kualitas guru erat kaitannya dengan profesionalisme guru. Profesionalisme menurut UU Nomor 14 Tahun 2005 tentang Guru dan Dosen adalah pekerjaan atau kegiatan yang dilakukan oleh seseorang dan menjadi sumber penghasilan kehidupan yang memerlukan keahlian, kemahiran, atau kecakapan yang memenuhi standar mutu atau norma tertentu serta memerlukan pendidikan profesi.

Australian Professional Standard for Teachers (AITSL, 2012), mengidentifikasi keterlibatan profesional dalam diskusi kolegial untuk tujuan meningkatkan pengetahuan dan praktik profesional sebagai indicator keahlian guru, serta dengan standar profesional untuk Queensland College of Teachers (QCT, 2006), praktik reflektif dan pembaharuan profesional digambarkan sebagai integral semua standar lainnya. Penekanan di kedua set standar memicu guru pendidik untuk memanfaatkan peluang dalam mempersiapkan keterlibatan dialog professional dan refleksi sebagai strategi untuk 
menarik guru melakukan kegiatan belajar profesional.

Indikator yang mempengaruhi profesionalisme guru menurut Usman (2006, p.19), kompetensi profesional secara spesifik dapat dilihat dari indikator- indikator adalah: (1) menguasai landasan pendidikan, yaitu mengenal tujuan pendidikan, mengenal fungsi sekolah dan masyarakat, serta mengenal prinsip-prinsip psikologi pendidikan, (2) menguasai bahan pengajaran, yaitu menguasai bahan pengajaran kurikulum pendidikan dasar dan menengah, menguasai bahan penghayatan, (3) menyusun program pengajaran, yaitu menetapkan tujuan pembelajaran, memilih dan mengembangkan bahan pengajaran, memilih dan mengembangkan strategi belajar mengajar, memilih media pembelajaran yang sesuai, memilih dan memanfaatkan sumber belajar, melaksanakan program pengaja-ran, menciptakan iklim belajar mengajar yang tepat, mengatur ruangan belajar, mengelola interaksi belajar mengajar. (4) menilai hasil dan proses pembelajaran yang telah dilaksanakan.

Menurut UU RI No. 14 Tahun 2005 tentang Guru dan Dosen, kompetensi profesional adalah kemampuan atau kompetensi yang berhubungan dengan penyesuaian tugas-tugas keguruan. Kompetensi ini merupakan kompetensi yang sangat penting dan langsung berhubungan dengan kinerja yang ditampilkan. Tingkat keprofesionalan seorang guru dapat dilihat dari kompetensi antara lain: (1) kemampuan untuk memahami landasan kependidikan, (2) pemahaman dalam bidang psikologi pendidikan, (3) kemampuan dalam penguasaan materi pelajaran sesuai dengan bidang studi yang diajarkannya, (4) kemampuan merancang dan memanfaatkan berbagai media dan sumber belajar, (5) kemampuan dalam melaksanakan evaluasi pembelajaran, (6) kemampuan dalam menyusun program pembelajaran, dan (7) kemampuan dalam melaksanakan penelitian dan berpikir ilmiah untuk meningkatkan kinerja.

Guru di kota Yogyakarta memiliki kompetensi yang berbeda-beda tingkatan tinggi rendahnya. Beberapa guru ada yang lulusan D-3, S-1 dan bahkan S-2. Di samping kualitas guru, hal yang mempengaruhi profesionalitas seorang guru adalah modal sosial guru, intensitas kegiatan MGMP (Musyawarah Guru Mata
Pelajaran) yang diadakan guru dan kompetensi yang dimiliki guru.

Beberapa hal yang perlu diperhatikan bahwa seiring dengan perkembangan modernitas zaman lunturnya rasa sosial kepedulian terhadap sesama manusia rentan memicu terjadinya konflik dan perpecahan. Guru sebagai agen perubahan harus di dukung dengan kelengkapan kompetensi guru sebagai transfer of knowledge yang harus menguasai ilmu yang akan disampaikan, bagaimana mengemas ilmu yang akan disampaikan, bagaimana mengkomunikasikan ilmu kepada siswa serta memahami perkembangan siswa.

Perkembangan siswa tersebut meliputi wawasan, sikap, ucapan dan perilaku kehidupan sehari-sehari siswa yang harus di evaluasi sehingga perkembangannya selalu ke arah yang lebih positif. Profesionalisme guru pada dasarnya dapat di upgrade ke dalam sebuah wadah kegiatan. Wadah kegiatan tersebut terdiri dari para guru mata pelajaran yang dinamakan MGMP. MGMP memiliki kegiatan yang berfungsi sebagai tempat sharing, bertukar informasi dan mengadakan berbagai macam kegiatan seperti seminar pendidikan yang fungsinya diharapkan mampu memicu peningkatan kualitas guru. Dengan kegiatan MGMP yang tercermin pada kualitas kegiatannya dan Intensitas kegiatan yang diadakan MGMP dapat memicu peningkatan kinerja guru yang profesional (Mulyasa, 2013: p.150-151). Dari penjelasan diatas menunjukkan bahwa ketiga variabel modal sosial, kompetensi guru dan intensitas kegiatan MGMP sangat penting perannya untuk meningkatan profesionalisme guru.

Cohen dan Prusak (2001, pp.1-2) berpendapat bahwa modal sosial merupakan hubungan yang aktif diantara manusia yang meliputi rasa percaya, saling pengertian, dan kesamaan nilai dan perilaku yang mengikat anggota dalam sebuah jaringan kerja yang memungkinkan adanya kerjasama. Sehingga apabila komponen-komponen dalam modal sosial tersebut terintegrasi dengan baik di sekolah dan dikembangkan dalam MGMP dapat meningkatkan mutu pendidikan.

Coleman (2011, pp.415-416) mengatakan bahwa modal sosial merupakan relasi sosial yang terbentuk ketika individu berupaya 
menggunakan sumber-sumber individual dengan efektif dan maksimal. Modal sosial dapat diartikan sebagai kumpulan sumber yang melekat dalam relasi keluarga dan dalam organisasi sosial komunitas yang bermanfaat untuk perkembangan kognitif sosial anak-anak atau pemuda. Berbagai macam bentuk modal sosial berupa relasi wewenang, relasi kepercayaan norma-norma pelaku kepentingan, sumber penguasaan, hak untuk bertindak, hubungan kekuasaan, hubungan kepercayaan, system pertukaran sosial, relasi wewenang, struktur wewenang, system kepercayaan bersifat dinamis, perilaku kolektif, dan tuntutan akan norma-norma yang efektif.

Masyarakat Indonesia bercirikan masyarakat kolektif yang ditandai tingginya interaksi antarmanusia. Hal ini merupakan salah satu manifestasi positif dari modal sosial yang tinggi. Kohesi sosial di sekolah dapat ditunjukkan melalui kegiatan komunitas yang memberi ruang terjadinya interaksi sosial pada individu yang cenderung di dasari rasa persahabatan dan persaudaraan. Seperti berkumpul berwisata bersama, acara syukuran datang ke pesta perkawinan, pengajian, makan-makan, ngobrol bersama dan sebagainya. Kegiatan ini menguatkan rasa kebersamaan, membangun rasa memiliki, memupuk rasa kasih sayang, meningkatkan komunikasi, dan membangun kesadaran kelompok. Kegiatan tersebut berdampak positif untuk menciptakan semangat kebersamaan, kerja keras dan komitmen dalam mencapai visi dan misi sekolah dalam upaya peningkatan kualitas pendidikan sekolah.

Pelaksanaan modal sosial, kompetensi guru yang baik juga menjadi prioritas untuk peningkatan profesionalitas guru dan kualitas pendidikan Indonesia. Menurut Suyanto (2013, p.1) secara umum ada tiga tugas guru sebagai profesi, yakni mendidik, mengajar, dan melatih. Dalam pencapaiannya seorang guru dituntut memiliki beberapa kemampuan dan kompetensi tertentu sebagai bagian dari profesionalisme guru. Kompetensi guru adalah salah satu faktor yang mempengaruhi tercapainya tujuan pembelajaran dan pendidikan disekolah. Kompetensi guru dapat dinilai penting sebagai alat seleksi dalam penerimaan calon guru, juga dapat dijadikan sebagai pedoman dalam rangka pembinaan dan pengembangan tenaga guru.
Berdasarkan UU No 14 tahun 2005 tentang guru dan dosen, kompetensi guru dapat dikategorikan menjadi empat macam yaitu kompetensi pedagogik, kompetensi kepribadian, kompetensi profesional dan kompetensi sosial. Keempat kompetensi tersebut harusnya dimilki oleh seorang guru untuk menjadi guru yang profesional.

Kota Yogyakarta menjadi lokasi yang diteliti karena Yogyakarta merupakan salah satu barometer kota pendidikan di Indonesia yang memiliki beragam kualitas sekolah, dari yang sangat berkualitas sampai dengan yang kurang berkualitas. Sekolah-sekolah dengan kualitas yang sangat baik memilki guru yang profesional sehingga mampu berjejaring luas dengan berbagai lembaga, baik dalam dan luar negeri. Sekolah yang baik mampu memanfaatkan modal sosial yang dimilikinya, mempunyai relasi yang baik antara guru-guru, kepala sekolah dan warga sekolah lainnya.

Berdasarkan pertimbangan tersebut, maka dipandang perlu untuk melakukan penelitian menyangkut profesionalisme guru yang melaksanakan tugas di Kota Yogyakarta dan faktor yang diduga berpengaruh, adalah modal sosial, kompetensi guru dan intensitas kegiatan MGMP. Penelitian ini nantinya dapat digunakan sebagai bahan evaluasi dan pertimbangan dalam pengambilan kebijakan yang berkaitan dengan peningkatan profesionalisme guru dan kualitas pembelajaran di Kota Yogyakarta.

\section{Metode Penelitian}

Penelitian ini menggunakan metode penelitian ex-post facto. Penelitian ex-post facto merupakan suatu penelitian yang dilakukan untuk meneliti peristiwa yang telah terjadi dan kemudian merunut ke belakang untuk mengetahui faktor-faktor yang dapat menyebabkan timbulnya kejadian tersebut. Pada penelitian ini variabel yang akan diteliti merupakan peristiwa yang telah terjadi. Sedangkan berdasarkan tingkat eksplanasinya, penelitian ini tergolong penelitian asosiatif kausal.

Pendekatan Penelitian

Penelitian ini menggunakan pendekatan kuantitatif. Menurut data penelitian pada pendekatan kuantitatif berupa angka-angka dan 
analisis menggunakan statistik. Alasan peneliti menggunakan pendekatan kuantitatif karena peneliti bermaksud untuk menghilangkan subjektifitas dalam penelitian

Variabel Penelitian

Variabel dalam penelitian ini meliputi; pertama variabel bebas (Independent Variable). Variabel bebas dalam penelitian ini adalah modal sosial (X1), kompetensi guru(X2), intensitas kegiatan MGMP (X3). Kedua variabel terikat (Dependent Variable). Variabel terikat dalam penelitian ini adalah profesionalisme guru (Y).

Populai dan Sampel Penelitian

Populasi dalam penelitian ini yaitu semua guru IPS SMP di Kota Yogyakarta yang tergabung dalam MGMP. Dalam hal ini, Kota Yogyakarta terdiri dari 16 SMP Negeri, 34 SMP Swasta Sementara untuk jumlah keseluruhan guru IPS ada 109 orang.

Teknik pengambilan sampel yang digunakan dalam penelitian ini adalah sampling jenuh yang merupakan teknik penentuan sampel di mana semua anggota populasi digunakan sebagai sampel. Hal ini sering dilakukan mengingat jumlah populasi relatif kecil atau penelitian yang ingin membuat generalisasi dengan kesalahan yang sangat kecil. Jadi sampel penelitian yang digunakan sejumlah 109 guru.

Teknik dan Instrumen Pengumpulan Data Kuesioner

Kuesioner yang peneliti gunakan yaitu angket tertutup. Kuesioner dalam penelitian ini digunakan untuk memperoleh data tentang modal sosial, kompetensi guru, intensitas kegiatan MGMP, dan profesionalisme guru.

Dokumentasi

Dalam melaksanakan metode dokumentasi, dilakukan terhadap benda-benda tertulis seperti buku-buku, majalah, dokumen, peraturan, notulen rapat, catatan harian, dan sebagainya. Dalam Penelitian ini, dokumentasi dilakukan untuk memperoleh data mengenai sekolah, jumlah guru, foto-foto mengenai pelaksanaan penelitian yang dilakukan.
Validitas dan Reliabilitas Instrumen

Uji Validitas Instrumen

Penelitian ini menggunakan validitas internal (teoritik) yaitu dengan menyusun kisikisi instrumen. Validitas konstruk berfokus pada kemampuan instrumen untuk mengukur gejala yang sesuai dengan definisinya. Pengujian instrument menggunakan Confirmatory Factor Analisys (CFA).

Pada angket validitas diambil dengan menggunakan one shoot method atau pengukuran sekali saja. Pengukuran hanya dilakukan sekali dan kemudian hasilnya dibandingkan dengan pertanyaan lain atau mengukur korelasi atau jawaban pertanyaan. Uji validitas setiap butirnya dapat dilihat pada tabel uji validitas yang terlampir, khususnya untuk kolom anti image matriks. Kriteria dikatakan valid apabila koefisien tersebut melebihi atau sama dengan 0,50. (Yamin dan Kurniawan, 2009: pp.185-186). Berikut nlai KMO masingmasing variabel:

\begin{tabular}{lc}
\multicolumn{2}{c}{ Tabel 1. Nilai KMO Variabel } \\
\hline \multicolumn{1}{c}{ Variabel } & KMO \\
\hline Profesionalisme Guru & 0,599 \\
Modal Sosial & 0,804 \\
Kompetensi Guru & 0,850 \\
Intensitas Kegiatan & 0,617 \\
MGMP & \\
Sumber: Data Primer yang Diolah
\end{tabular}

Dari Tabel 1 dapat disimpulkan bahwa nilai KMO untuk masing-masing variabel yaitu variabel profesionalisme guru, modal sosial, kompetensi guru dan intensitas kegiatan MGMP telah memenuhi kriteria di mana memiliki koefisien lebih dari 0,50. Artinya instrumen tersebut dinyatakan valid dan layak untuk digunakan dalam penelitian.

\section{Uji Reliabilitas Instrumen}

Dalam penelitian ini, digunakan teknik reliabilitas internal. Untuk mengetahui reliabilitas angket digunakan uji Cronbach Alpha ( $\alpha$ ) karena instrument angket termasuk kedalam jenis data interval yaitu dengan skala 15 untuk hasil uji instrumen berupa angket. 
Tabel 2.Kriteria Koefisien Reliabilitas

\begin{tabular}{|c|c|c|}
\hline No. & Koefisien Reliabilitas & Kategori \\
\hline 1 & $<0,500$ & $\begin{array}{l}\text { Reliabilitas } \\
\text { rendah }\end{array}$ \\
\hline 2 & $0,500-0,700$ & $\begin{array}{c}\text { Reliabiltas } \\
\text { moderat }\end{array}$ \\
\hline 3 & $0,700-0,900$ & $\begin{array}{c}\text { Reliabilitas } \\
\text { tinggi }\end{array}$ \\
\hline 4 & $>0,900$ & $\begin{array}{l}\text { Reliabilitas } \\
\text { sempurna }\end{array}$ \\
\hline
\end{tabular}

Tabel 3. Nilai Reliabilitas Variabel

\begin{tabular}{lc}
\hline \multicolumn{1}{c}{ Variabel } & $\begin{array}{c}\text { Cronbach Alpha } \\
(\boldsymbol{\alpha})\end{array}$ \\
\hline Profesionalisme Guru & 0,722 \\
Modal Sosial & 0,877 \\
Kompetensi Guru & 0,836 \\
Intensitas Kegiatan MGMP & 0,749 \\
\hline
\end{tabular}

Sumber: Data Primer yang Diolah

Dari Tabel 3 diketahui nilai relibailitas masing-masing variabel. Masing-masing variabel memiliki nilai $>0,07$ atau kategori reliabilitas tinggi. Kategori tersebut menandakan bahwa alat ukur (instrumen) dapat dipercaya atau diandalkan dalam penelitian.

Uji Prasyarat Analisis

Uji Normalitas

Tabel 4. Rangkuman Uji Normalitas

\begin{tabular}{|c|c|c|c|}
\hline Variabel & K-S-Z & $\mathbf{P}$ & Ket. \\
\hline $\begin{array}{c}\text { Profesionalisme } \\
\text { Guru }\end{array}$ & 1,349 & 0,052 & Normal \\
\hline $\begin{array}{l}\text { Modal Sosial } \\
\text { Guru }\end{array}$ & 1,018 & 0,251 & Normal \\
\hline $\begin{array}{l}\text { Kompetensi } \\
\text { Guru }\end{array}$ & 7,13 & 0,689 & Normal \\
\hline $\begin{array}{c}\text { Intensitas } \\
\text { Kegiatan } \\
\text { MGMP }\end{array}$ & 1,331 & 0,058 & Normal \\
\hline
\end{tabular}

Berdasarkan Tabel 4 variabel profesionalisme guru, modal sosial guru, kompetensi guru dan intensitas kegiatan MGMP memiliki nilai $\mathrm{P}$ (Asymp Sig 2-tailed $>0,05$. Maka tidak ada perbedaan antara distribusi teoritik dan distribusi empirik sehingga dapat diartikan bahwa penyebaran data normal. Hasil uji normalitas menunjukkan bahwa semua variabel penelitian memenuhi asumsi normalitas data.

Uji Linearitas

Tabel 5. Uji Linearitas Variabel

\begin{tabular}{ccc}
\hline Variabel & Signifikansi & Keterangan \\
\hline $\mathrm{X} 1 \rightarrow \mathrm{Y}$ & 0,149 & Linear \\
$\mathrm{X} 2 \rightarrow \mathrm{Y}$ & 0,422 & Linear \\
$\mathrm{X} 3 \rightarrow \mathrm{Y}$ & 0,745 & Linear \\
\hline
\end{tabular}

Sumber: Data Primer yang Diolah

Berdasarkan Tabel 5 dapat diketahui nilai signifikansi 0,745 , artinya nilai tersebut lebih besar dari 0,05 $(>0,05)$ maka dapat disimpulkan bahwa data tersebut memiliki hubungan linear. Dengan data yang linier tersebut dapat diketahui nilai prediksinya atau dengan kata lain dapat dianalisis.

Uji Multikolinearitas

Tabel 6. Uji Multikoleniaritas

\begin{tabular}{|c|c|c|}
\hline Variabel & VIF & Keterangan \\
\hline Modal Sosial & 1,587 & $\begin{array}{c}\text { Tidak terjadi } \\
\text { multikoleniaritas }\end{array}$ \\
\hline Kompetensi Guru & 1,364 & $\begin{array}{c}\text { Tidak terjadi } \\
\text { multikoleniaritas }\end{array}$ \\
\hline $\begin{array}{c}\text { Intensitas } \\
\text { Kegiatan MGMP }\end{array}$ & 1,199 & $\begin{array}{c}\text { Tidak terjadi } \\
\text { multikoleniaritas }\end{array}$ \\
\hline
\end{tabular}

Berdasarkan Tabel 6 dapat diambil kesimpulan bahwa nilai Variance Inflation Factor (VIF) masing-masing variabel tersebut berada diantara 1-10, maka dapat disimpulkan bahwa variabel Modal Sosial, Kompetensi Guru, dan Intensitas Kegaitan MGMP tidak ditemukan adanya korelasi yang tinggi atau interkorelasi antara variabel bebas lainnya. Artinya tidak terjadi Multikoleniaritas.

Uji Heteroskedestisitas

Tabel 7. Uji Heteroskedastisitas

\begin{tabular}{|c|c|c|}
\hline Variabel & Sig & Keterangan \\
\hline $\begin{array}{l}\text { Modal } \\
\text { Sosial }\end{array}$ & 0,097 & $\begin{array}{c}\text { Tidak Terjadi } \\
\text { Heteroskedastisitas }\end{array}$ \\
\hline $\begin{array}{l}\text { Kompetensi } \\
\text { Guru }\end{array}$ & 0,290 & $\begin{array}{c}\text { Tidak Terjadi } \\
\text { Heteroskedastisitas }\end{array}$ \\
\hline $\begin{array}{c}\text { Intensitas } \\
\text { Kegiatan } \\
\text { MGMP }\end{array}$ & 0,858 & $\begin{array}{c}\text { Tidak Terjadi } \\
\text { Heteroskedastisitas }\end{array}$ \\
\hline
\end{tabular}


Tabel 7 menunjukkan bahwa semua variabel mempunyai nilai signifikansi lebih besar dari $0,05(>0,05)$ sehingga dapat disimpulkan bahwa model regresi pada penelitian ini tidak terjadi heteroskedastisitas.

\section{Hasil Penelitian dan Pembahasan}

Deskripsi Data Profesionalisme Guru

Variabel profesionalisme guru digolongkan kedalam 3 kategori kecenderungan variabel yaitu rendah, sedang dan tinggi.

Tabel 8. Distribusi Kecenderungan Kategori Variabel Profesionalisme

\begin{tabular}{cccc}
\hline Kategori & $\begin{array}{c}\text { Rentang } \\
\text { skor }\end{array}$ & Frek. & $\begin{array}{c}\text { Prosen } \\
\text { tase }\end{array}$ \\
\hline Rendah & $<90$ & 0 & 0 \\
Sedang & $90-120$ & 105 & $96 \%$ \\
Tinggi & $>120$ & 4 & $4 \%$
\end{tabular}

Total $109 \quad 100 \%$

Sumber: Data primer yang diolah

Tabel 8 menunjukkan bahwa frekuensi kategori tinggi sebesar 4 (4\%), sedang sebesar $105(96 \%)$, rendah sebesar $0(0 \%)$, dan rendah sebesar $16(19,7 \%)$. Berdasarkan nilai tersebut dapat digambarkan dengan diagram lingkaran sebagai berikut:

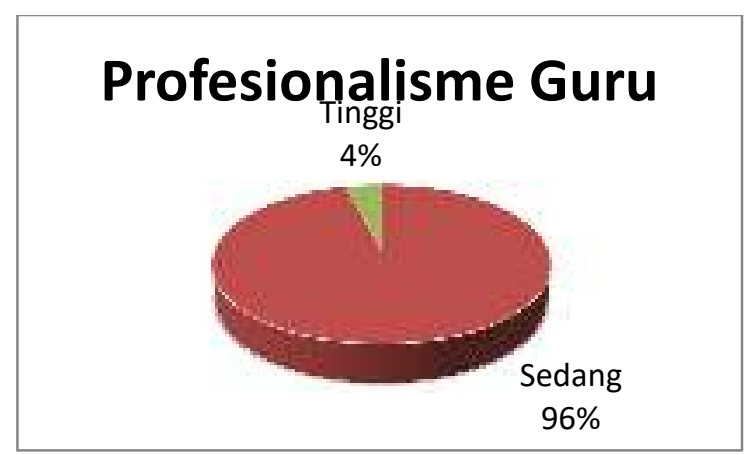

Gambar 1. Diagram Kecenderungan Kategori Profesionalisme Guru

Berdasarkan Gambar 1 guru menempati jumlah mayoritas sebanyak $105(96 \%)$ pada kategori sedang. Dengan demikian dapat disimpulkan bahwa tingkat profesionalisme guru berada pada taraf sedang
Deskripsi Data Modal Sosial

Variabel modal sosial guru digolongkan kedalam 3 kategori kecenderungan variabel yaitu tinggi, sedang dan rendah.

Tabel 9. Distribusi Kecenderungan Kategori Variabel Modal Sosial

\begin{tabular}{cccc}
\hline Kategori & $\begin{array}{c}\text { Rentang } \\
\text { skor }\end{array}$ & Frek. & Prosentase \\
\hline Rendah & $<77$ & 7 & $6 \%$ \\
Sedang & $77-103$ & 88 & $81 \%$ \\
Tinggi & $>103$ & 14 & $13 \%$ \\
\hline Total & 109 & $100 \%$ & \\
\hline Sumber: Data primer yang diolah &
\end{tabular}

Tabel 9 menunjukkan bahwa frekuensi kategori tinggi sebesar 14 (13\%), sedang sebesar $88(81 \%)$, dan rendah sebesar $7(6 \%)$. Berdasarkan nilai tersebut dapat digambarkan dengan diagram lingkaran sebagai berikut:

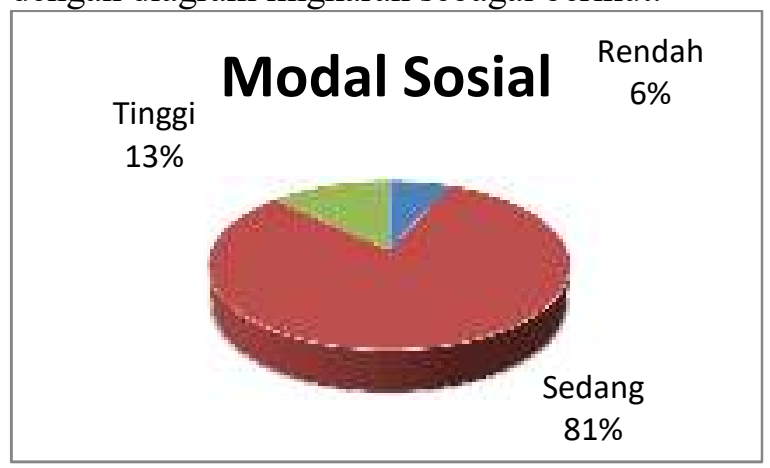

Gambar 2. Diagram Kecenderungan Kategori Modal Sosial

Berdasarkan Gambar 2 guru menempati jumlah mayoritas sebanyak $81 \quad(81 \%)$ pada kategori sedang Dengan demikian dapat disimpulkan bahwa tingkat modal sosial guru berada pada taraf sedang.

\section{Deskripsi Data Kompetensi Guru}

Variabel kompetensi guru digolongkan kedalam 3 kategori kecenderungan variabel yaitu tinggi, sedang, dan rendah. 
Tabel 10 . Distribusi Kecenderungan Kategori Variabel Kompetensi Guru

\begin{tabular}{cccc}
\hline Kategori & $\begin{array}{c}\text { Rentang } \\
\text { skor }\end{array}$ & Frek. & Prosentase \\
\hline Rendah & $<62$ & 0 & 0 \\
Sedang & $62-82$ & 87 & $80 \%$ \\
Tinggi & $>82$ & 22 & $20 \%$ \\
\hline Total & 109 & $100 \%$ & \\
\hline Sumber: Data primer yang diolah &
\end{tabular}

Tabel 10 menunjukkan bahwa frekuensi kategori tinggi sebesar 22 (20\%), sedang sebesar $87(80 \%)$, dan rendah sebesar $0(0 \%)$. Berdasarkan nilai tersebut dapat digambarkan dengan diagram lingkaran sebagai berikut:

\section{Kompetensi Guru}

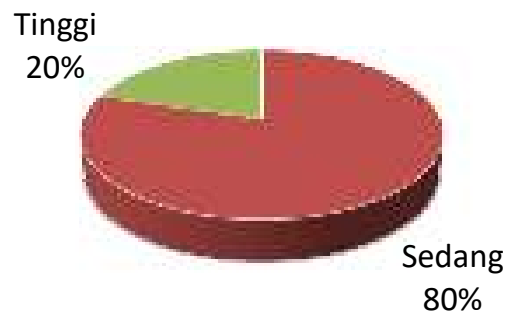

Gambar 3. Diagram Kecenderungan Kategori Kompetensi Guru

Berdasarkan Gambar 6 guru menempati jumlah mayoritas sebanyak $87(80 \%)$ pada kategori sedang. Dengan demikian dapat disimpulkan bahwa tingkat kompetensi guru berada pada taraf sedang.

\section{Deskripsi Data Intensitas Kegiatan MGMP}

Variabel Intensitas Kegiatan MGMP digolongkan kedalam 3 kategori kecenderungan variabel yaitu tinggi, sedang, dan rendah.

Tabel 11. Distribusi Kecenderungan Kategori Variabel Intensitas Kegiatan MGMP

\begin{tabular}{cccc}
\hline Kategori & $\begin{array}{c}\text { Rentang } \\
\text { skor }\end{array}$ & Frek. & Prosentase \\
\hline Rendah & $<64$ & 0 & 0 \\
Sedang & $64-86$ & 80 & $73 \%$ \\
Tinggi & $>86$ & 29 & $27 \%$ \\
\hline Total & 109 & $100 \%$ & \\
\hline Sumber: Data primer yang diolah &
\end{tabular}

Tabel 11 menunjukkan bahwa frekuensi kategori tinggi sebesar 29 (27 \%), sedang sebesar $80(73 \%)$, dan rendah sebesar $0(0 \%)$. Berdasarkan nilai tersebut dapat digambarkan dengan diagram lingkaran sebagai berikut:

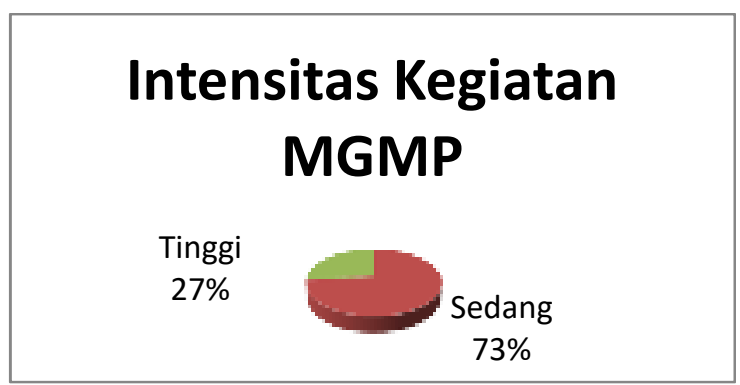

Gambar 4. Diagram Kecenderungan Kategori Intensitas Kegiatan MGMP

Berdasarkan diagram lingkaran diatas guru menempati jumlah mayoritas sebanyak $80(73 \%)$ pada kategori sedang. Dengan demikian dapat disimpulkan bahwa tingkat intensitas kegiatan MGMP IPS SMP Yogyakarta berada pada taraf sedang.

Hasil Uji Hipotesis

Persamaan Regresi Analisis

Analisis persamaan regresi digunakan untuk mengetahui pengaruh modal sosial guru $\left(X_{1}\right)$, kompetensi guru $\left(X_{2}\right)$, dan intensitas kegiatan MGMP $\left(X_{3}\right)$, terhadap profesionalisme guru (Y). Untuk menguji persamaan regresi berdasarkan unstandardized coefficients beta dengan rumus sebagai berikut:

$$
\mathrm{Y}=\mathrm{a}+b_{1} X_{1}+b_{2} X_{2}+b_{3} X_{3}+\mathrm{e}
$$

\section{Uji Partial (Uji t)}

Di bawah ini akan dipaparkan tentang pengujian hipotesis secara parsial (uji t). Uji t dilakukan untuk mengetahui adanya pengaruh modal sosial guru $\left(X_{1}\right)$, kompetensi guru $\left(X_{2}\right)$, dan intensitas kegiatan MGMP $\left(X_{3}\right)$ terhadap profesionalisme guru (Y) secara parsial. Rangkuman uji hipotesis secara parsial dapat dilihat pada tabel di bawah ini: 
Tabel 12. Estimasi Persamaan Regresi Linier Parsial

\begin{tabular}{lcr}
\hline Variabel & $\begin{array}{c}\text { Unstandard } \\
\text { ized } \\
\text { coefficient } \\
\text { Beta }\end{array}$ & Signifikansi \\
\hline $\begin{array}{l}\text { Constant } \\
\text { Modal Sosial } \\
\text { Guru }\end{array}$ & 78,768 & 0,000 \\
$\begin{array}{l}\text { Kompetensi } \\
\text { Guru }\end{array}$ & 0,279 & 0,001 \\
$\begin{array}{l}\text { Intensitas } \\
\text { Kegiatan } \\
\text { MGMP }\end{array}$ & 0,263 & 0,042 \\
\hline Sumber: Data primer yang diolah & \\
\hline
\end{tabular}

Berdasarkan Tabel 12 semua variabel memiliki nilai probabilitas yang ditunjukkan pada kolom signifikansi. Dengan demikian dapat disimpulan bahwa modal sosial $\left(X_{1}\right)$ secara parsial berpengaruh positif terhadap professionalisme guru (Y), besar koefisien ( $X_{1}$ ) sebesar 0,279 dengan nilai konstanta sebesar 78,768. berdasarkan nilai tersebut dapat disusun persamaan regresinya sebagai berikut:

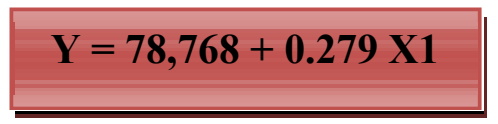

Artinya jika $X_{1}$ mengalami kenaikan 1\% maka nilai profesionalisme guru $(\mathrm{Y})$ akan mengalami kenaikan sebesar 0,279. Koefisien bernilai positif artinya terjadi hubungan yang searah antara variabel modal sosial dengan professionalisme guru, semakin tinggi nilai koefisien regresi variabel modal sosial guru maka semakin tinggi nilai profesionalisme guru.

Kompetensi Guru $\left(X_{2}\right)$ secara parsial berpengaruh positif terhadap profesionalisme guru $(Y)$, besar koefisien kompetensi guru $\left(X_{2}\right)$ sebesar 0,263 dengan nilai konstanta sebesar 78,768. berdasarkan nilai tersebut dapat disusun persamaan regresinya sebaga berikut:

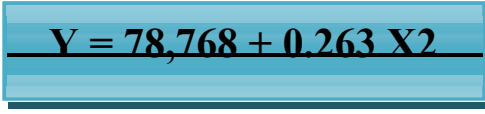

Artinya jika $X_{2}$ mengalami kenaikan 1\% maka nilai professionalisme guru (Y) akan mengalami kenaikan sebesar 0,263. Koefisien bernilai positif artinya terjadi hubungan yang searah antara variabel kompetensi guru dengan professionalisme guru, semakin tinggi nilai koefisien regresi variabel kompetensi guru maka semakin tinggi nilai profesionalisme guru.

Intensitas Kegiatan MGMP $\left(X_{3}\right)$ secara parsial berpengaruh negatif terhadap profesionalisme guru (Y), besar koefisien kompetensi guru $\left(X_{3}\right)$ sebesar -0.256 dengan nilai konstanta sebesar 78.768. berdasarkan nilai tersebut dapat disusun persamaan regresinya sebaga berikut:

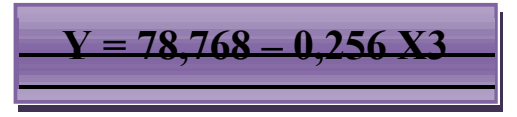

Artinya jika intensitas kegiatan MGMP $X_{3}$ mengalami kenaikan $1 \%$ maka nilai professionalisme guru (Y) akan mengalami penurunan sebesar 0,256. Koefisien bernilai negatif artinya terjadi hubungan yang berlawanan antara variabel kompetensi guru dengan profesionalisme guru, semakin tinggi nilai koefisien regresi variabel intensitas kegiatan MGMP maka semakin tinggi nilai profesionalisme guru

\section{Uji Simultan (Uji F)}

Di bawah ini akan dipaparkan tentang pengujian hipotesis secara simultan (uji F). Uji $\mathrm{F}$ (Fisher) dilakukan untuk mengetahui ada tidaknya pengaruh modal sosial $\left(X_{1}\right)$, kompetensi guru $\left(X_{2}\right)$, dan intensitas kegiatan MGMP $\left(X_{3}\right)$ terhadap profesionalisme guru (Y) secara bersama-sama.

Tabel 13. Hasil Uji Regresi secara bersama-sama

\begin{tabular}{cccc}
\hline Model & $\begin{array}{c}\text { Mean } \\
\text { Square }\end{array}$ & F & Sig. \\
\hline $\begin{array}{c}\text { Regresion } \\
\text { Residual } \\
\text { Total }\end{array}$ & 473,774 & 9,851 & 0,000 \\
\hline \multicolumn{2}{l}{ Sumber: } & Data Primer yang Diolah
\end{tabular}

Berdasarkan Tabel 13 menunjukkan bahwa model regresi dapat digunakan untuk memprediksi profesionalisme guru atau dapat diakatakan bahwa modal sosial $\left(X_{1}\right)$, kompetensi guru $\left(X_{2}\right)$, dan intensitas kegiatan MGMP $\left(X_{3}\right)$, secara bersama-sama berpengaruh terhadap 
profesionalisme guru (Y) di MGMP IPS di Kota Yogyakarta.

Hasil statistik uji $\mathrm{F}$ untuk variabel intensitas kegiatan MGMP diperoleh nilai signifikansi sebesar 0,000 dan $F_{\text {hitung }}$ sebesar 9,851 dengan demikian dapat disimpulkan bahwa hipotesis yang menyatakan "Terdapat pengaruh simultan modal sosial, kompetensi guru dan Intensitas Kegaiatan MGMP terhadap Professionalisme Guru" terbukti. Artinya modal sosial guru, kompetensi guru dan intensitas kegiatan MGMP berpengaruh secara simultan terhadap profesionalisme guru.

\section{Uji Keabsahan Beta}

Pengujian ini dilakukan untuk mengetahui variabel yang paling dominan mempengaruhi profesionalisme guru dengan melihan koefisien beta. Untuk mengetahui variabel yang paling dominan mempengaruhi profesionalisme guru, maka dapat dilihat pada tabel di bawah ini:

\section{Tabel 14. Uji Keabsahan Beta}

\begin{tabular}{cccc}
\hline Model & $\begin{array}{c}\text { Standardized } \\
\text { Coefficients }\end{array}$ & T & Sig \\
\cline { 2 - 3 } Beta & & \\
\hline $\begin{array}{c}\text { Constant } \\
\text { Modal }\end{array}$ & 0,368 & 3,436 & 0,001 \\
$\begin{array}{c}\text { Sosial } \\
\text { Kompetensi } \\
\quad \text { Guru }\end{array}$ & 0,206 & 2,061 & 0,042 \\
$\begin{array}{c}\text { Intensitas } \\
\text { Kegiatan } \\
\text { MGMP }\end{array}$ & $-0,227$ & $-2,413$ & 0,018 \\
\hline Sumber: Data Primer yang Diolah &
\end{tabular}

Berdasarkan Tabel 14 dapat diketahui nilai beta variabel modal sosial $\left(X_{1}\right)$, yang mempunyai nilai beta paling tinggi yaitu 0.368 , sehingga dapat disimpulkan bahwa variabel yang paling dominan mempengaruhi hasil belajar (Y) adalah variabel modal sosial.

\section{Uji Koefisien Determinasi (adjust $\boldsymbol{R}^{2}$ )}

Di bawah ini akan dipaparkan tentang sumbangan relatif untuk tiap variabel dengan menggunakan uji koefesien determinasi. Koefisien determinasi secara simultan ( $\mathrm{R}$ square atau $R^{2}$ ) digunakan untuk mengukur sumbangan dari variabel modal sosial $\left(X_{1}\right)$, kompetensi guru $\left(X_{2}\right)$, dan intensitas kegiatan $\operatorname{MGMP}\left(X_{3}\right)$, terhadap profesionalisme guru (Y) secara simultan. Hasil uji determinasi $R^{2}$ dapat dilihat pada tabel di bawah ini:

\begin{tabular}{ccc} 
Tabel & 15. Hasil uji koefisien determinasi $\boldsymbol{R}^{2}$ \\
\hline Model & $\mathbf{R}$ & Adjusted R Square
\end{tabular}

\begin{tabular}{ccc}
\hline 1 & 0,469 & 0,220 \\
\hline Sumber: Data Primer yang Diolah
\end{tabular}

Nilai Adjusted R Square yang ditunjukkan pada Tabel 15 sebesar 0,220. Artinya variabel modal sosial $\left(X_{1}\right)$, kompetensi guru $\left(X_{2}\right)$, dan intensitas kegiatan MGMP $\left(X_{3}\right)$, terhadap profesionalisme guru (Y) mampu menjelaskan $22 \%$ variasi kepada variabel profesionalisme guru atau dengan kata lain $22 \%$ perubahan terjadi pada variabel profesionalisme guru $(\mathrm{Y})$, sisanya sebesar 78\% dijelaskan oleh faktorfaktor selain dari ketiga variabel bebas tersebut.

Pembahasan

Pengaruh modal sosial terhadap profesionalisme guru SMP IPS di Kota Yogyakarta

Berdasarkan data statistik dapat di deskripsikan bahwa variabel modal sosial (X1) dari 109 guru, 6\% atau 7 guru yang memiliki modal sosial guru rendah, $81 \%$ atau 88 guru yang memiliki modal sosial guru sedang dan $13 \%$ atau 14 guru yang memiliki modal sosial tinggi. Hal ini menunjukkan bahwa modal sosial guru memberikan kontribusi terhadap perkembangan profesionalisme guru.

Hasil uji hipotesis menunjukkan bahwa terdapat pengaruh antara modal sosial (X1) terhadap profesionalisme guru $(\mathrm{Y})$. Estimasi pengaruh modal sosial terhadap profesionalisme guru dapat dilihat pada nilai koefisien beta yaitu sebesar 0,279 yang bernilai positif. Sifat positif tersebut digunakan untuk memprediksi semakin bagus modal sosial guru maka akan semakin bagus profesionalisme guru dalam bekerja, sedangkan koefisien determinasi atau besarnya sumbangan pengaruh modal sosial (X1) terhadap profesionalisme guru $(\mathrm{Y})$ adalah $14,5 \%$. 
Hal ini diperkuat dengan penelitian yang dilakukan Thornfeldt $(2014$, p.77) terhadap 44 sekolah di kota Copenhagen membuktikan bahwa dimana guru yang memiliki modal sosial lebih tinggi mampu meningkatkan kualitas siswa lebih signifikan daripada sekolah-sekolah yang memiliki tingkat modal sosial yang lebih rendah, terlepas dari faktor-faktor sosial ekonomi yang menentukan komposisi siswa.

Pengaruh kompetensi guru terhadap
profesionalisme guru SMP IPS di Kota
Yogyakarta

Berdasarkan data statistik dapat di deskripsikan bahwa variabel kompetensi guru (X2) dari 109 guru, $80 \%$ atau 87 guru yang memiliki kompetensi guru sedang dan $20 \%$ atau 22 guru yang memiliki komepetensi guru tinggi. Hal ini menunjukkan bahwa kompetensi guru memberikan kontribusi terhadap perkembangan profesionalisme guru.

Hasil uji hipotesis menunjukkan bahwa terdapat pengaruh antara kompetensi guru (X2) terhadap profesionalisme guru (Y). Estimasi pengaruh kompetensi guru terhadap profesionalisme guru dapat dilihat pada nilai koefisien beta yaitu sebesar 0,263 yang bernilai positif. Sifat positif tersebut digunakan untuk memprediksi semakin bagus kompetensi guru maka akan semakin bagus profesionalisme guru dalam bekerja, sedangkan koefisien determinasi atau besarnya sumbangan pengaruh kompetensi guru (X2) terhadap profesionalisme guru (Y) adalah $12 \%$.

Hasil analisis tersebut senada dengan penelitian yang dilakukan oleh Rubio dalam journal ENSAYOS (2009, pp35-46) yang berjudul "Effective Teachers-Professional and Personal Skills". Dari jurnal tersebut dapat disimpulkan bahwa untuk menjadi guru yang efektif dan profesional tidak hanya memiliki pengetahuan yang baik, tetapi juga organisasi, manajemen dan kemampuan komunikasi, mampu mengatur instruksi, dan memberikan penilaian yang relevan dan evaluasi yang adil. Selain itu, guru profesional bertanggung jawab untuk menciptakan iklim kelas yang kondusif untuk meningkatkan antusiasme, motivasi dan hubungan guru dan murid yang interaktif.
Pengaruh intensitas kegiatan MGMP terhadap profesionalisme guru SMP IPS di Kota Yogyakarta

Berdasarkan data statistik dapat di deskripsikan bahwa variabel intensitas kegiatan MGMP (X3) dari 109 guru, 73\% atau 80 guru yang memiliki intensitas kegiatan MGMP sedang dan $27 \%$ atau 29 guru yang intensitas kegiatan MGMP tinggi. Hal ini menunjukkan bahwa modal sosial guru memberikan kontribusi terhadap perkembangan profesionalisme guru.

Berdasarkan hasil uji hipotesis di atas menunjukkan bahwa terdapat pengaruh antara intensitas kegiatan MGMP (X3) terhadap profesionalisme guru (Y). Estimasi pengaruh intensitas kegiatan MGMP terhadap profesionalisme guru dapat dilihat pada nilai koefisien beta yaitu sebesar $-0,256$ yang bernilai negatif. Sifat negatif tersebut digunakan untuk memprediksi semakin sering kegiatan MGMP dilakukan maka akan menganggu guru dalam kegiatan belajar mengajar yang terntunya akan berpengarug terhadap profesionalisme guru dalam bekerja, sedangkan koefisien determinasi atau besarnya sumbangan pengaruh antara intensitas kegiatan MGMP (X3) terhadap profesionalisme guru (Y) adalah $0,1 \%$.

Pemberdayaan kegiatan MGMP yang berkualitas dibuktikan dalam penelitian National Council of Teachers of English (2010, pp.1-2) Hasil penelitian menunjukkan bahwa masyarakat belajar guru, di Indonesia disebut dengan istilah MGMP (Musyawarah Guru Mata Pelajaran) dapat meningkatkan kualitas guru, dan kualitas guru adalah faktor yang paling penting dalam meningkatkan prestasi siswa. Masyarakat belajar guru dapat didefinisikan sebagai kelompok guru yang "terus menyelidiki praktek mengajar dan, sebagai hasilnya, menemukan, membuat, dan bernegosiasi makna baru yang meningkatkan praktek mengajar guru. Hal tersebut sepaham dengan penelitian yang dilakukan oleh Peran MGMP dalam meningkatkan profesionalisme guru tergolong tinggi $(73,7 \%)$, sebagai mediator peningkatan kompetensi guru tergolong tinggi (57,9\%), sebagai supporting agency dalam inovasi manajemen kelas dan sekolah tergolong tinggi (57,9\%), peran MGMP sebagai collaborator sekolah tergolong tinggi $(57,9 \%)$, sebagai evaluator sekolah tergolong tinggi $(68,4 \%)$, serta 
dalam supervisi akademik dan klinis tergolong tinggi yaitu sebesar 73,7\%.

Pengaruh secara simultan antara modal sosial, kompetensi guru dan intensitas kegiatan MGMP terhadap profesionalisme guru IPS SMP di kota Yogyakarta

Berdasarkan data statistik dapat di deskripsikan bahwa variabel profesionalisme guru (Y) dari 109 guru, 96\% atau 105 guru yang memiliki tingkat profesionalisme sedang dan $4 \%$ atau 4 guru yang memiliki tingkat profesionalisme tinggi. Hal ini menunjukkan bahwa profesionalisme guru memiliki banyak faktor yang mempengaruhi untuk lebih diperhatikan. Khususnya pada MGMP IPS Kota Yogyakarta masih banyak guru yang berada pada kategori sedang.

Hasil uji hipotesis menunjukkan bahwa terdapat pengaruh secara simultan antara modal sosial (X1), kompetensi guru (X2) dan intensitas kegiatan MGMP (X3) terhadap profesionalisme guru (Y). Estimasi pengaruh modal sosial, kompetensi guru dan intensitas kegiatan MGMP terhadap profesionalisme guru dapat dilihat pada nilai koefisien beta yaitu sebesar 0,286 yang bernilai positif. Sifat positif tersebut digunakan untuk memprediksi bagus modal sosial, kompetensi guru, dan semakin sering mengikuti kegiatan MGMP akan berpengarug terhadap profesionalisme guru dalam bekerja, sedangkan koefisien determinasi atau besarnya sumbangan pengaruh modal sosial (X1), kompetensi guru (X2) dan intensitas kegiatan MGMP (X3) terhadap profesionalisme guru (Y) adalah 22\%.

Hasil penelitian di atas didukung oleh penelitian Hamdan \& Chia lai lai (2015, p.274) menunjukkan bahwa cara mengajar guru yang efektif secara simultan dipengaruhi oleh pengembangan kegiatan professional hal ini di tunjukkan dengan nilai determinasi dan probabilitas $(r=0,676, p<0,05)$, pengembangan profesionalisme guru meliputi pengembangan kompetensi, pengembangan modal sosial melalui sebuah pelatihan pengembangan profesionalisme seperti forum MGMP. Variabel pendukung dalam penelitian ini berupa pengalaman mengajar sebagai salah satu faktor yang mempengaruhi guru dengan pengaruh $(\mathrm{r}=0,621, \mathrm{p}<0,05)$, dan variabel latar belakang sekolah dengan pengaruh $(\mathrm{r}=0,193, \mathrm{p}<0,05)$
Semakin tinggi profesionalisme guru tentunya akan menggambarkan tingkat modal sosial yang meliputi jaringan individu yang luas, mempunyai tingkat kepercayaan tinggi, mampu bekerjasama, memiliki komunikasi, interaksi yang berkualitas sehingga informasi mudah didapat. Sehingga akan memudahkan guru dalam proses penyelesaian masalah dan pencapain tujuan. Dengan adanya modal sosial mendukung kegiatan MGMP lebih mudah dilaksanakan baik dari segi intensitas, efektifitas maupun kualitas. Oleh karena itu semakin tinggi profesionalisme, maka guru tersebut akan memiliki modal sosial, kompetensi guru, dan intensitas kegiatan MGMP berjalan sesuai dengan tujuan yang efektif dan berkualitas.

\section{Simpulan, Implikasi dan Saran}

Simpulan

Berdasarkan diskripsi data hasil penelitian dan uraian pembahasannya yang telah dikemukakan kesimpulan bahwa modal sosial guru berpengaruh positif terhadap profesionalisme guru bidang keahlian IPS di SMP Kota Yogyakarta yang tergabung dalam MGMP IPS dengan kontribusi efektif sebesar $14,5 \%$, sehingga variabel modal sosial guru hanya mempengaruhi sebagian kecil terhadap tingkat profesionalisme guru dan $85,5 \%$ dipengaruhi oleh variabel lain.

Kompetensi guru berpengaruh positif terhadap profesionalisme guru bidang keahlian IPS di SMP Kota Yogyakarta yang tergabung dalam MGMP IPS dengan kontribusi efektif sebesar 12\%, sehingga variabel kompetensi guru hanya mempengaruhi sebagian kecil terhadap tingkat profesionalisme guru dan $88 \%$ dipengaruhi oleh variabel lain.

Intensitas kegiatan MGMP berpengaruh negatif terhadap profesionalisme guru bidang keahlian IPS di SMP Kota Yogyakarta yang tergabung dalam MGMP IPS dengan kontribusi efektif sebesar $0,1 \%$. Prediktor yang terlalu kecil atau mendekati nol (0), menunjukkan bahwa prediktor tersebut tidak memberikan arti untuk keperluan prediksi, sehingga dalam 
penelitian ini dapat disimpulkan bahwa pengaruh negatif intensitas kegiatan MGMP masih berada pada taraf normal dan tidak berpengaruh terhadap profesionalisme guru.

Modal sosial guru, kompetensi guru, dan Intensitas kegiatan MGMP secara simultan memberikan pengaruh terhadap profesionalisme guru pada bidang keahlian IPS di SMP Kota Yogyakarta dengan kontribusi efektif sebesar 22\%, sehingga variabel modal sosial guru, kompetensi guru dan intensitas kegiatan MGMP hanya mempengaruhi sebagian kecil terhadap tingkat profesionalisme guru dan $75 \%$ dipengaruhi oleh variabel lain.

\section{Implikasi}

Penelitian ini menunjukkan bahwa perkembangan profesionalisme guru harus didukung berbagai upaya yaitu peningkatan kompetensi guru, pemahaman modal sosial guru dan berbagai kegaiatan MGMP sebagai penunjang aktivitas kegiatan ilmiah untuk menjadi guru yang profesional. Secara parsial modal sosial guru yang efektif akan mendukung perkembangan profesionalisme guru, sehingga guru perlu pemahaman lebih dalam memaknai modal sosial agar mampu mengaplikasikannya dengan maksimal. Jika guru memiliki kompetensi yang baik akan meningkatkan profesionalisme guru. Guru yang profesional memiliki empat kompetensi dasar yaitu kompetensi pedagogik, kompetensi kepribadian, kompetensi sosial, dan kompetensi profesional. Jika sering terlibat dalam kegiatan MGMP, guru akan bertemu dengan rekan sejawatnya dan berdiskusi tentang metode, media dan teknik pembelajaran yang relevan. Guru yang profesional sering mengikuti kegiatan MGMP sebagai wujud komitmen terhadap pekerjaanya. Proses menjadi guru yang profesional diperlukan beberapa strategi dan dipengaruhi oleh berbagai faktor. Tempat penelitian di daerah lain dapat dijadikan sebagai bahan pertimbangan untuk mengetahui seberapa besar dampak yang dihasilkan dari faktor kompetensi guru, modal sosial guru dan intensitas kegiatan MGMP terhadap profesionalisme guru ataupun terdapat faktor-faktor lainnya yang belum bisa diprediksikan.

Hasil belajar siswa tergantung pada kompetensi guru dalam melakukan pembelajaran, antara lain pengetahuan, keterampilan, sikap dan perilaku guru. Untuk itu guru hendaknya terlibat aktif dalam kegiatan MGMP terkait, terlibat pengetahuan dengan isu-isu saat ini dan mengikuti berbagai kegiatan ilmiah lain. Modal sosial sebagai dasar semangat kemandirian, kebersamaan dan kepedulian untuk mengatasi persoalan secara bersama sehingga memudahkan pencapaian tujuan sebagai guru yang profesional.

Saran

Berdasarkan pembahsan dan simpulan selanjutnya dapat diajukan saran bagi Dinas Pendidikan Kota Yogyakarta hasil penelitian ini dapat dijadikan bahan pertimbangan dalam mengambil kebijakan, terutama yang berkaitan dengan peningkatan profesionalisme guru melalui kegiatan MGMP. Kegiatan MGMP harus berdasarkan kualitas guru sesuai yang dibutuhkan, tidak hanya keterlaksanaan sebuah kegiatan dan pemberian dana. Sehingga perlu diteliti lebih detail tentang indikator keberhasilan MGMP dalam meningkatankan profesionalisme guru.

Bagi guru IPS SMP agar senantiasa meningkatkan profesionalisme diri berdasarkan pengembangan kompetensi dan praktik modal sosial dengan aktif dalam berbagai kegiatan MGMP, karena kompetensi guru, modal sosial guru dan intensitas MGMP yang di dasarkan pada kualitas pelaksanaan kebutuhan guru memiliki pengaruh secara simultan untuk meningkatkan profesionalisme guru.

Pengaruh secara simultan menunjukkan bahwa dalam meningkatkan profesionalisme 
guru akan lebih mudah tercapai jika memiliki kompetensi guru, melakukan praktik modal sosial dan terlibat aktif dalam kegiatan MGMP yang berkualitas. Dalam praktik upaya peningkatannya guru IPS SMP dapat memaksimalkan MGMP IPS sebagai wadah peningkatan kompetensi guru dan praktik modal sosial dalam mencapai esensi tujuan terbentuknya MGMP.

Bagi para peneliti agar penelitian ini semakin sempurna, maka disarankan kepada para peneliti lain untuk mengadakan penelitian lanjutan dengan melibatkan faktor-faktor lain yang belum diteliti. Selain itu, disarankan juga untuk memperbanyak populasi dan sampel penelitian serta menambah waktu pelaksanaan penelitian.

\section{Daftar Pustaka}

Abdul Rahim Hamdan \& Chia lai lai. (2015). The relationship between teachers' factors and effective teaching, Asian social science vol.11, no 12 (274)

Australian Institute of Teaching and School Leadership (AITSL). (2012). The Nationa Professional Standards.

Cohen, D, \& Prusak, L. (2001). In good company: how social capital makes organizations work.Cambridge: Harvard Business Press.

Coleman, J.S. (2011). Dasar-Dasar Teori Sosial Foundations Of Social Theory.Bandung: Nusamedia

DIKTI, R (2013, Desember 5). Skor PISA: Indonesia nyaris jadi juru kunci. Diambil kembali dari www.kopertis12.or.id. Pada 15 November 2015

Mulyasa, E. (2013). Uji kompetensi dan penilaian kinerja guru. Bandung: PT. Remaja Rosdakarya
National Council of Teachers of English. (2010). Teachers Learning Communities. Inggris: The Council Chronicle.

Queensland College of Teachers. (2006). Professional Standards for Queensland Teachers

Rainsch, S. (2004). Dynamic strategic analysis: demystifying simple success strategies (Wiesbaden: Deutscher UniversitastsVerlag).

Rubio, C.M. (2009). Effective TeachersProfessional and Personal Skills. Journal ENSAYOS No. 24. 2009 (3546). Universidad de Castilla-la Mancha

Thornfeld, C. (2014). Elementary school teachers' social capital \& its association with student achievement, master thesis university of Copenhagen departemen of sociologi. Copenhagen.

Yamin, S. \& Kurniawan, H. (2009). SPSS complete:Teknik analisis statistik terlengkap dengan software SPSS. Jakarta: Salemba Infotek.

Suryarahman, E. \& Hastuti, H. (2014). Kinerja Guru IPS SMP Bersertifikasi Profesi Berdasarkan Standar Kompetensi Guru di Kabupaten Lombok Utara. Harmoni Sosial: Jurnal Pendidikan IPS, [S.l.], v. 1, n. 2. ISSN 2460-7916. Available at: $<$ http://journal.uny.ac.id/index.php/hsj pi/article/view/2435/2022>. Date accessed: 20 apr. 2016.

Suyanto \& Jihad, A. (2013). Menjadi guru profesional. Jakarta: Esensi Erlangga Group

Undang-Undang Republik Indonesia Nomor 14 Tahun 2005 Tentang Guru dan Dosen. 
UNDP. (2014). 2014 human development report. Diambil dari http://www.undp.org/ content/undp/ en/home/librarypage/hdr/2014 -human -development-report.html pada tanggal 15 Oktober 2015.

Usman, M.U. (2006). Menjadi guru profesional. Bandung: PT. Remaja Rosdakarya

Utami, N. (2003). Kualitas dan profesionalisme guru. artikel diambil pada tanggal 4 Desember 2003 dari http://www.pikiranrakyat.com/cetak/102/15/0802/html pada tanggal 14 Oktober 2015

\section{Biodata Penulis}

Reza Armin Abdillah Dalimunthe lahir di Yogyakarta, 20 Agustus 1990. Lulus S-1 Pendidikan Ilmu Pengetahuan Sosial (IPS) FIS Universitas Negeri Yogyakarta tahun 2013, dan lulus S-2 Pendidikan IPS Pascasarjana Universitas Negeri Yogyakarta pada tahun 2016. Alamat e-mail yang bisa dihubungi rezaabdillahdalimunthe@gmail.com. 